\title{
Bioactive and functional compounds of mixed beverages based on fruits and vegetables
}

\author{
Patrícia da Silva Machado ${ }^{1}$ - Rafaela da Silva Melo ${ }^{1}$. Ana Beatriz Silva Araújo ${ }^{1}$ Taciene Carvalho Mesquita ${ }^{1}$. \\ Ítalo Careli Gondim ${ }^{1}$. Elídio Zaidine Maurício Zitha ${ }^{1}$ • Elisângela Elena Nunes Carvalho ${ }^{1}$. \\ Eduardo Valério de Barros Vilas Boas ${ }^{1} \cdot$ Luiz Carlos de Oliveira Lima $^{1}$
}

Received: 8 August 2019 / Accepted: 28 November 2019 / Published online: 3 April 2020

(c) Springer Nature Switzerland AG 2020

\begin{abstract}
In recent years, the demand for fruits and vegetables has increased in several countries. Thereby, the consumption of natural beverages increased, and specifically those with claims of functional properties. However, there is a clear need for further studies on the beneficial effects of these beverages, and greater attention should be given to brands that use this information in a manner that is unconcerned with consumer health. This work aimed to study the physical-chemical composition and bioactive and functional compounds of some brands of natural drinks marketed in Brazil. Six brands of natural drinks were acquired and analyzed for $\mathrm{pH}$, titratable acidity (\%), soluble solids, total sugars, color, total phenolics, vitamin C, $\beta$-carotene/linoleic acid, DPPH and dietary fiber. The drinks analyzed are in accordance with the literature for acidity, except the ' $E$ ' brand. The sugar content found in three brands ('A,' $B$-Le' and ' $D$ ') was higher than reported on the labels, and the ' $A$ ' brand misleads the consumer by stating that their drink is 'zero sugar.' In general, the drinks showed yellowish color, except the ' $E$ ' brand with greenish coloration. The brand ' $A$ ' also had higher levels of vitamin $C$ than established by law. The amount of phenolic compounds was higher in the ' $A$ ' and ' $F$ ' brands. The antioxidant content was higher in ' $A$, ' $C$ ' and ' $F$.'The ' $D$ ' and ' $F$ ' brands were shown as sources of dietary fiber. The content of some brands analyzed is in disagreement with their labels which represents a danger to consumers with some kind of food restriction.
\end{abstract}

Keywords Juice $\cdot$ Antioxidants $\cdot$ Dietary fiber $\cdot$ Detox $\cdot$ DPPH

\section{JEL Classification 111}

Mathematics Subject Classification 92-02

\section{Introduction}

Demand for fruit and vegetables has increased in recent years in several countries in response to increased public awareness of the benefits of healthy eating. It has been suggested that consumption of antioxidant-rich foods may delay or prevent many diseases [1, 2]. Therefore, the guide to health promotion and disease prevention in the
USA and around the world includes recommendations for daily consumption of a variety of fruits and vegetables, since they have significant amounts of bioactive compounds, especially vitamins, minerals and fiber [3]. To help ingesting adequate amounts of fruits and vegetables, juices are a practical alternative [4].

In order to increase the consumption of natural drinks, fruit juice companies are expanding their niche markets

Patrícia da Silva Machado, patriciamachado1918@hotmail.com | ${ }^{1}$ Federal University of Lavras, UFLA, University Campus, Cx. P. 3037, Lavras, MG 37200-000, Brazil. 
into a category that now extends beyond traditional fruit juices like orange and apple for a line of innovative vegetable blends, given the clear trend toward higher consumption of natural and less processed products, and consumers are willing to pay more for products that offer what they are looking for, especially when it comes to health and wellness [5].

There is evidence suggesting that the juices of different fruits contain bioactive components and, having this information, some companies producing natural juices use them on their labels, even claiming detox properties. However, there is a clear need for larger, well-controlled, long-term studies with well-defined results. Most studies had a limited sample size of gender and ethnicity, as well as short treatment periods and focus on early biomarkers rather than expensive, but more meaningful functional results $[3,4]$.

This paper aims to study the physicochemical composition and bioactive compounds of some brands of natural drinks marketed in Brazil, some of which claim on their labels to have detoxifying properties, in order to know their compositions confronting them with their labels and verify the content of its bioactive compounds.

\section{Materials and methods}

The eight natural drinks from six different brands were purchased in the Lavras, Minas Gerais, Brazil trade. The brands 'A,' $C$,' $E$ ' and ' $F$ ' were selected for this study because they declare on their label that they are detox, the brand ' $\mathrm{B}$ ' for being sold as a natural drink and has the term 'DTOX' on its label, inducing consumers to think that it is a detox drink, the brand ' $\mathrm{D}$ ' was selected because its own name and marketing suggest selling healthiness to its consumers. The brands were coded as ' $A$, ' $B$, ' $C$,' $D$,' $E$ ' and ' $F$.' The ' $B$ ' brand was found in the orange (B-Or), passion fruit (B-PF) and lemon (B-Le) flavors. The description of the presentation, method of preparation, whether or not it is detox, sugar content and dietary fiber given on the package labeling are given in Table 1. Table 2 shows the ingredients of each brand. Among the evaluated brands, five are marketed nationally and only the brand ' $E$ ' is marketed in the state of Minas Gerais, Brazil. Only brand ' $A$ ' states the amount of vitamin C ( $45 \mathrm{mg} / 200 \mathrm{~mL}$ ) and brand 'B' does not explicitly state that juices are detox, but uses the word 'DTOX' on their packaging. All drinks used were within the expiration date indicated on the packaging/or label. The drinks were taken to the Food Chemical and Biochemical Analysis Laboratory of the Food Science Department of the Federal University of Lavras and evaluated for $\mathrm{pH}$, titratable acidity (\%) expressed as citric acid, soluble solids, total sugars, color, total phenolics, vitamin $C$, $\beta$-carotene/linoleic acid, DPPH and dietary fiber.

The $\mathrm{pH}$ was determined using a Tec $3 \mathrm{MP} \mathrm{pH}$ meter (TEC$N A L)$ according to the Association of Official Analytical Chemists [6] (AOAC) technique. The titratable acidity was determined by titration with $0.01 \mathrm{~mol} / \mathrm{L}$ sodium hydroxide $(\mathrm{NaOH})$ solution, using phenolphthalein as an indicator, according to the Adolfo Lutz Institute [7]. Results were expressed as percent citric acid. For the determination of soluble solids, a PAL-1 portable digital refractometer (ATAGO) was used. Results were expressed as percent soluble solids [6]. Total sugars were determined by the antrona method [8]. Results were expressed as a percentage. The coloring was determined on a Minolta CR-400 colorimeter, with determination in CIE mode $L^{*} a^{*} b^{*}$. The $L^{*}$ coordinate represents how light or dark the sample is, with values ranging from 0 (all black) to 100 (all white), commonly used to check the darkening. The hue angle $\left(h^{\circ}\right)$ refers to the tint, commonly used as a synonym for color, where $0^{\circ}$ represents pure red, $90^{\circ}$ pure yellow, $180^{\circ}$ pure green and $270^{\circ}$ pure blue. Chroma $\left(C^{*}\right)$ is related to the purity of the hue, which varies from intense or highly chromatic (values close to 60) to neutral (white, gray, black), values close to zero [9]. Total phenolics were determined by the Folin-Ciocalteau method [10]. The phenolic content was calculated from the equation of the straight line obtained from the
Table 1 Description of natural drinks according to their labels

\begin{tabular}{llllll}
\hline & Presentation & Preparation & Detox? & Sugars & Dietary fiber \\
\hline 'A'Brand & Powder & $20 \mathrm{~g} / 200 \mathrm{~mL}$ & YES & $5,0 \mathrm{~g} / 200 \mathrm{~mL}$ & No sign. \\
'B-Or'Brand & Liquid & RC & DTOX & $10.0 \mathrm{~g} / 200 \mathrm{~mL}$ & No sign. \\
'B-PF'Brand & Liquid & RC & DTOX $^{\mathrm{d}}$ & $6.0 \mathrm{~g} / 200 \mathrm{~mL}$ & No sign. \\
'B-Le'Brand & Liquid & RC brand & DTOX & $6.0 \mathrm{~g} / 200 \mathrm{~mL}$ & No sign. \\
'C'Brand & Power & $1.4 \mathrm{~g} / 200 \mathrm{~mL}$ & YES & N.D. & No sign. \\
'D'Brand & Liquid & RC & NO & $15.24 \mathrm{~g} / 200 \mathrm{~mL}$ & $0.33 \mathrm{~g} / 200 \mathrm{~mL}$ \\
'E'Brand & Power & $1 \mathrm{~g} / 200 \mathrm{~mL}$ & YES & N.D. & N.D. \\
'F'Brand & Liquid & RC & YES & $24 \mathrm{~g} / 200 \mathrm{~mL}$ & $5.1 \mathrm{~g} / 250 \mathrm{~mL}$ \\
\hline
\end{tabular}

${ }^{\mathrm{a}} R C$ Ready for consumption, ${ }^{\mathrm{b}} \mathrm{ND}$ No declaration, ${ }^{\mathrm{c}}$ Not significant quantity, ${ }^{\mathrm{d}}$ This brand does not claim that the product is Detox, but has this written on the front of the label 
Table 2 List of ingredients provided on drinks labels. Source: Natural drinks label

Ingredients

'A'Brand Maltodextrin, dehydrated cabbage powder, dehydrated spinach powder, orange pulp, blueberry pulp, apple pulp, dehydrated parsley powder, citric acid acidulant, guar gum thickener, sucralose sweetener, chlorophyll natural dye, selenium, ascorbic acid, niacinamide (3ibofla), thiamine mononitrate (vitamin B1), riboflavin (vitamin B2), pyridoxine (vitamin B6), cobalamin (vitamin B12), vitamin A acetate (vitamin A), ferric pyrophosphate (iron), folic acid, zinc sulfate (zinc) and flavorings

'B-Or' Brand Water, whole orange juice, cabbage, mint, spinach, ginger, whole lime juice and citric acid acidulant

'B-PF'Brand Water, whole orange juice, whole passion fruit juice, apple juice, cabbage, mint, spinach, ginger, whole lime juice and citric acid acidulant

'B-Le' Brand Water, wholemeal lemon juice, apple juice, cabbage, mint, spinach, ginger, holy grass and citric acid acidulant

' $C$ 'Brand Organic green tea leaf powder (matcha-Camelia sinensis), citric acid acidulant, pineapple-like aroma with mint, maltodextrin, sodium citrate acidity regulator, sucralose and acesulfame-k sweeteners, dehydrated pineapple pulp (pineapple juice, maltodextrin and citric acid acidulant), tricalcium phosphate antiumectant

'D'Brand Water, pineapple juice and mint

' $\mathrm{E}$ 'Brand This brand markets the prepared powder in bulk without informing the ingredients. The instruction of preparation is given by the sellers

'F'Brand Kiwi, pineapple, concentrated juice (apple, lemon), green tea extract, mint, chlorophyll, fruit pectin stabilizer

standard gallic acid curve. Results were expressed in milligrams of gallic acid equivalent (EAG) $100 \mathrm{~mL}^{-1}$ drink. Ascorbic acid content (after oxidation to dehydroascorbic acid) was determined by the colorimetric method using 2,4-dinitrophenylhydrazine according to Strohecker and Henning [11]. The determination of antioxidant activity by the $\beta$-carotene/linoleic acid method was performed according to the methodology described by Almeida et al. [12]. Results were expressed as percent inhibition of oxidation. The determination of antioxidant activity by the DPPH radical sequestration method was performed according to the description of Brand-Williams et al. [13], adapted by Rufino et al. [14]. Results were expressed as percentage of free radical sequestration (\% SRL). Total dietary fiber (FAT), soluble dietary fiber (FS) and insoluble dietary fiber (FI) were determined by the enzymatic-gravimetric method suggested by AOAC [6]. Results were expressed as percentage of fiber. Results were expressed as $\mathrm{mg}$ of ascorbic acid $100 \mathrm{~mL}^{-1}$ drink.

Analyzes were performed with three replicates in triplicate. The results were evaluated by univariate statistical analysis (ANOVA) and means test (Scott Knott, $p \leq 0.05$ ) were performed using the Sisvar software [15].

\section{Results}

The ' $E$ ' brand had a pH higher than 6.0 and this was the highest value found, followed by the 'D,' $B-O$ Or' $^{\prime}$ and 'A' brand. The 'B-PF' and ' $F$ ' brands had lower $\mathrm{pH}$ than the aforementioned brands and were statistically equal. The 'B-Le' and ' $\mathrm{C}$ ' brands had the lowest $\mathrm{pH}$ values (Fig. 1).

To titratable acidity, the ' $F$ ' brand had the highest value, followed by the 'B-Le' brand. The drinks 'A,'B-Or' and 'B-PF'

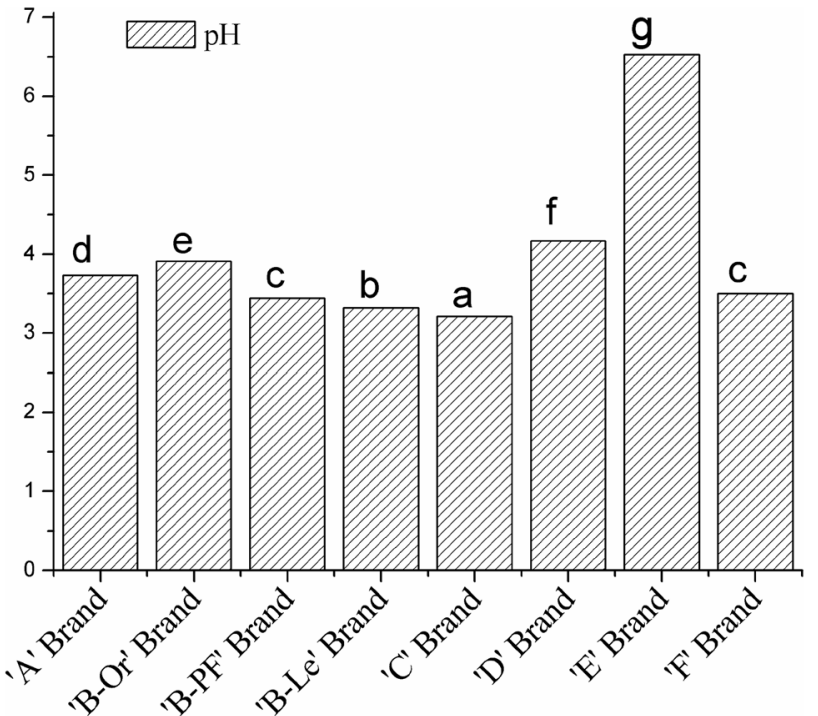

Fig. 1 Mean of $\mathrm{pH}$ from six brands of industrialized juices claiming 'natural.' Results were submitted to the Scott-Knott test at 5\% significance level

were statistically the same. The brand C and D had lower values than those previously mentioned and were equal to each other. The $\mathrm{E}$ brand obtained the lowest titratable acidity value when compared to the others (Fig. 2).

Regarding the soluble solids content, the ' $F$ ' brand stood out, followed by the ' $D$ ' brand and then by the ' $A$ ' and 'B-Le' brands that showed no difference between them. The 'B-Or' brand had the fourth highest average, the 'B-PF' the fifth and the ' $C$ ' and ' $E$ ' the lowest averages (Fig. 3). As with soluble solids analysis, the ' $F$ ' brand had the highest total sugars value followed by the ' $\mathrm{D}$ ' brand. The 'B-Or' and 'B-Le' brand were equal with third highest average, and the 


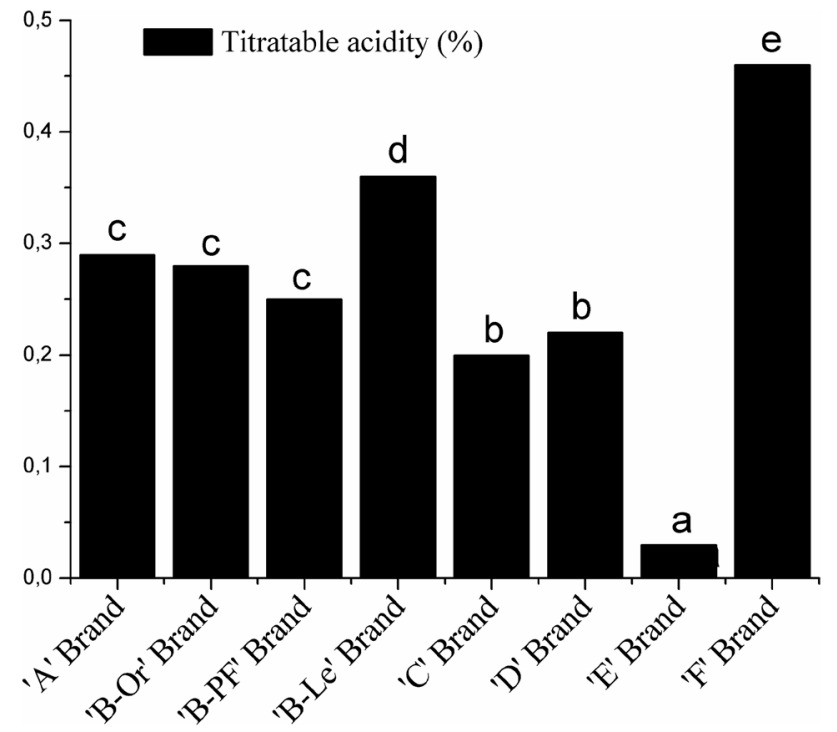

Fig. 2 Mean of titratable acidity (\%) values expressed as citric acid from six brands of industrialized juices claiming 'natural.' Results were submitted to the Scott-Knott test at $5 \%$ significance level

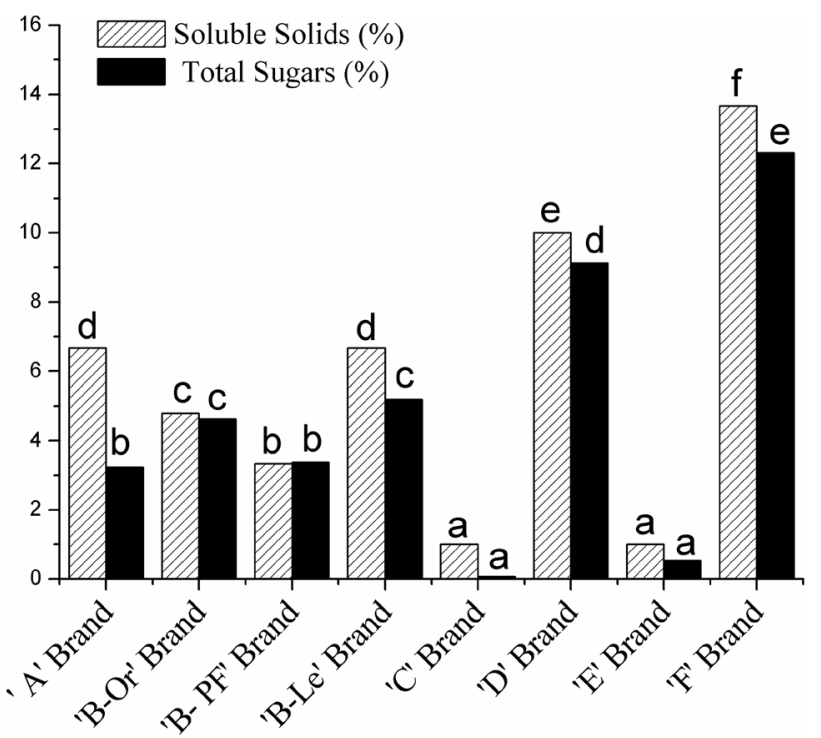

Fig. 3 Average values of soluble solids (\%) and total sugars (\%) of six brands of industrialized juices claiming 'natural.' Results were submitted to the Scott-Knott test at $5 \%$ significance level

' $A$ ' and 'B-PF' brands showed the fourth highest average and the lowest values were found in the ' $C$ ' and ' $E$ ' brands (Fig. 3).

The lightest drink was 'B-Or' followed by the ' $\mathrm{D}$ ' brand (Fig. 4). The brands 'B-PF' and ' $F$ ' were equal to each other. The ' $A$ ' brand got a higher brightness than ' $C$ ' and the ' $E$ ' brand was the darkest.

The chroma or color saturation was also higher in the 'B-Or' brand and the ' $\mathrm{C}$ ' and ' $\mathrm{E}$ ' brands had the lowest

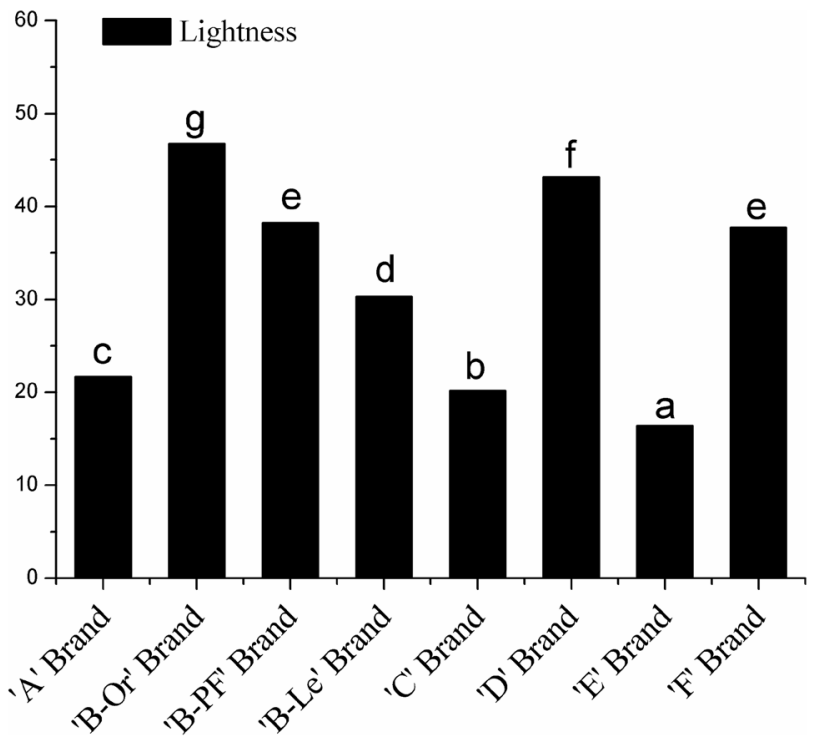

Fig. 4 Average values of lightness of six brands of industrialized juices claiming 'natural.' Results were submitted to the Scott-Knott test at $5 \%$ significance level

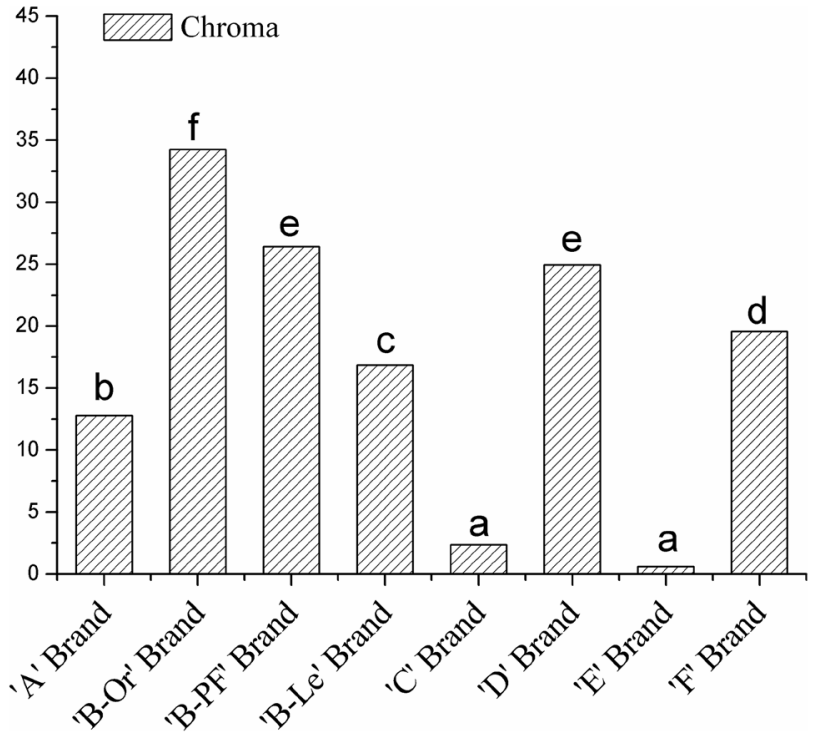

Fig. 5 Average values of chroma of six brands of industrialized juices claiming 'natural.' Results were submitted to the Scott-Knott test at $5 \%$ significance level

values. The 'B-PF' and ' $D$ ' drinks were the same and the other three brands were different from each other (Fig. 5).

Regarding the hue angle, the brand ' $E$ ' had the highest average, green color, followed by 'C','yellowish green color. The other drinks did not vary with yellow color (Fig. 6).

The brand 'A' stood out with respect to the value of total phenolic compounds, which was 2.2 times higher than the second higher brand $(F)$. The ' $D$ ' brand scored the third highest average, and this was higher than the ' $\mathrm{C}$ ' and ' $\mathrm{B}-\mathrm{Or}^{\prime}$ 


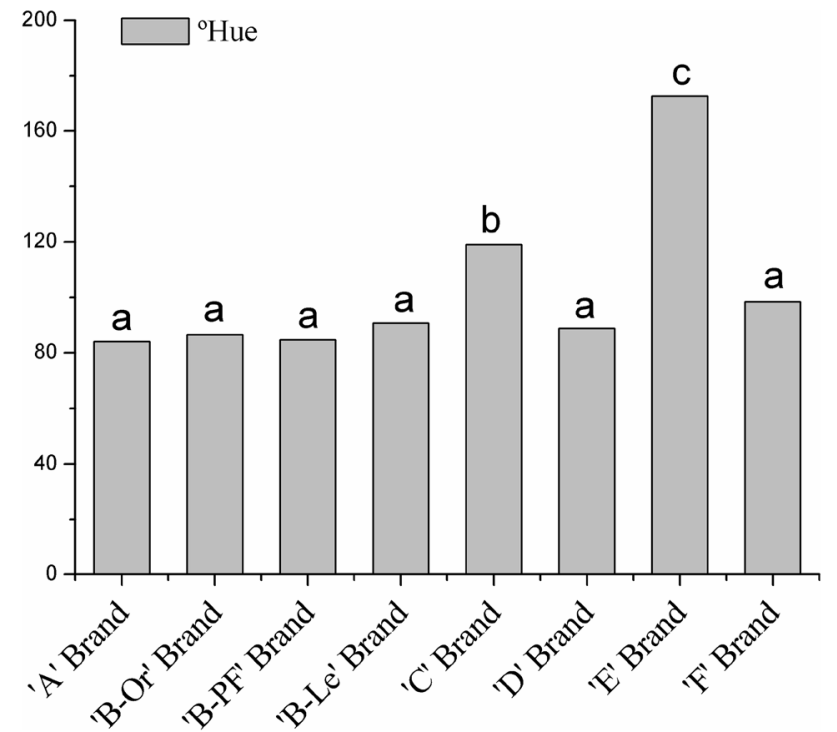

Fig. 6 Average values of ${ }^{\circ}$ hue of six brands of industrialized juices claiming 'natural.' Results were submitted to the Scott- Knott test at $5 \%$ significance level

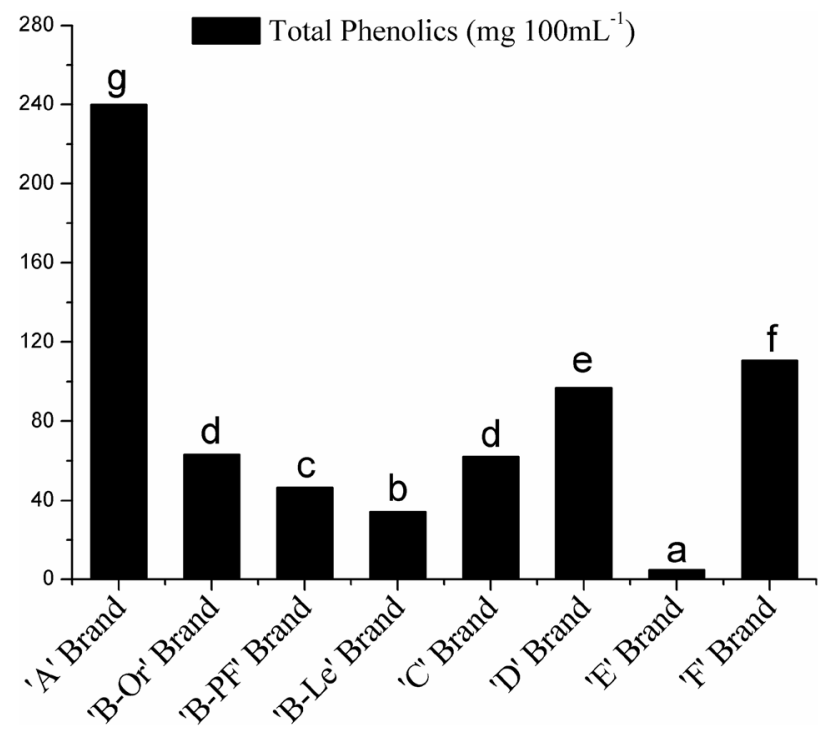

Fig. 7 Total phenolics mean values (mg $100 \mathrm{~mL}^{-1}$ ) of six brands of industrialized juices claiming 'natural.' Results were submitted to the Scott-Knott test at 5\% significance level

brands that were equal to each other. The lowest averages were from the brands 'B-PF,' $B$-Le' and 'E' (Fig. 7).

Vitamin $C$ content was also higher in the ' $A$ ' brand, followed by the 'B-Or,'B-PF,'B-Le,' ${ }^{\prime}$ ' and 'D' brands. The ' $C^{\prime}$ and ' $E$ ' brands had lower vitamin $C$ averages (Fig. 8).

The antioxidant activity measured by the $\beta$-carotene/linoleic acid system was not statistically significant $(p>0.05)$, with mean values of $63.63 \%$ (data not shown). The sequestration of the DPPH' radical was best performed by the ' $A$ '

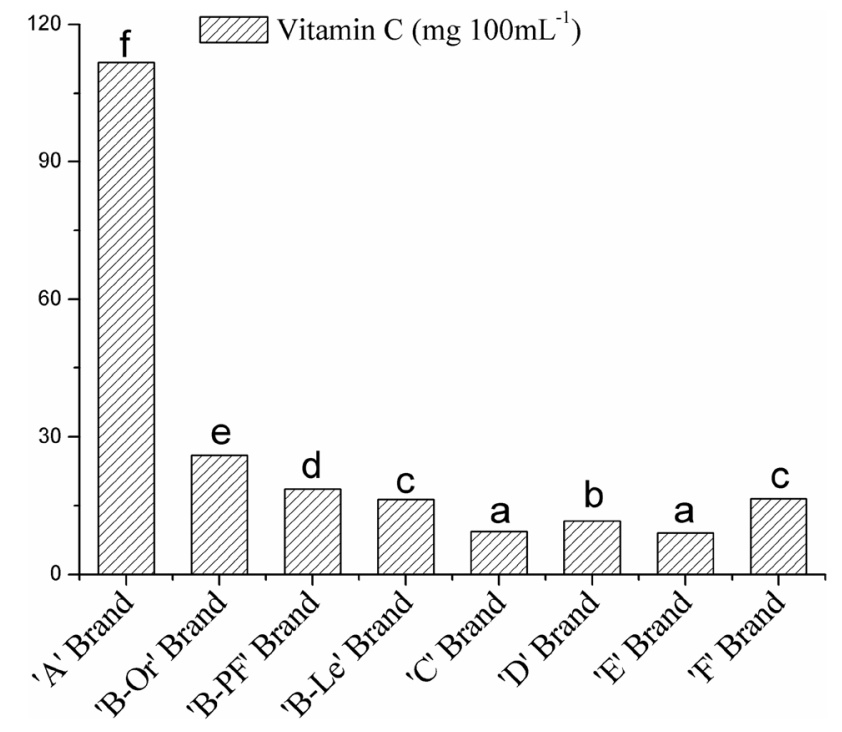

Fig. 8 Vitamin $\mathrm{C}$ (mg $100 \mathrm{~mL}^{-1}$ ) mean values of six brands of industrialized juices claiming 'natural.' Results were submitted to the Scott-Knott test at 5\% significance level

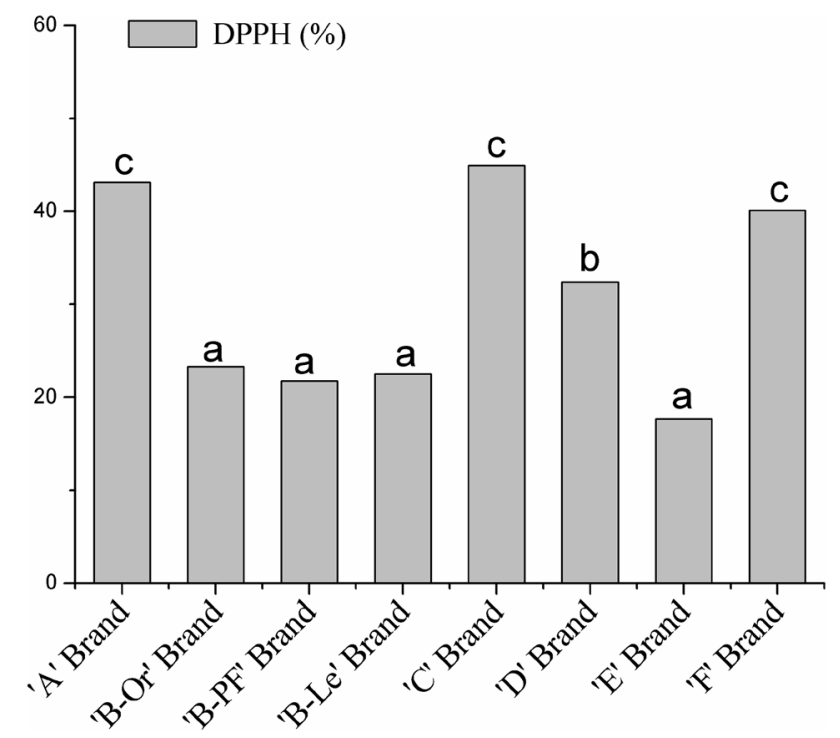

Fig. 9 DPPH (\%) mean values of six brands of industrialized juices claiming 'natural.' Results were submitted to the Scott-Knott test at $5 \%$ significance level

(powder), ' $C$ ' (powder) and ' $F$ ' (ready-to-drink) drinks that were statistically the same. The ' $\mathrm{D}$ ' brand obtained the second best result and the other brands were equal to each other (Fig. 9). 


\section{Discussion}

From a microbiological point of view, the $\mathrm{pH}$ of beverages should not be higher than 4.5 because it favors the growth of Clostridium botulinum [16]. Except for 'E' brand, all other brands had a pH below 4.5, even those that sell their beverages in powdered form.

The high $\mathrm{pH}$ value and low acidity value of the ' $\mathrm{E}$ ' brand could be justified by its ingredients and the beverage preparation mode that is taught by sellers. The information of ingredients is not available on their label which is a danger to consumers since the composition is not known. There are several vegetables that contain naturally anti-nutritional and/or toxic substances and depending on the amount ingested can represent serious health risks to those who consume them [17].

The total sugar content found in 'A, 'B-Le' and ' $D$ ' brands was $22.84 \%, 42.20 \%$ and $16.54 \%$ higher than the label, respectively. The 'B-Or' brand 7 was $4 \%$ lower than the label. In the 'B-PF' and ' $F$ ' brands, the values found were the same as stated on their labels. Only the brand ' $C$ ' and ' $E$ ' do not declare the values of sugars. It is interesting to note that in almost all brands analyzed the soluble solids content was higher than the total sugar content. This can be attributed to the fact that soluble solids consist mostly of sugars, but other substances are soluble such as organic acids and mineral [18], which may have contributed to the increase of this variable.

The brand ' $A$ ' claims on its label that the drink is 'zero sugar'; however, according to National Health Surveillance Agency in Brazil (ANVISA-Agência Nacional de Vigilância Sanitária) Resolution (RDC) No. 360 [19], the non-significant amount of carbohydrate present in a serving of food must be less than or equal to $0.5 \mathrm{~g}$ in order to use the term 'does not contain' or 'zero' and, the sugar value found in this brand was higher than that established by ANVISA. The 'C 'brand, in turn, has lower sugar values than established by RDC No. 360. This brand declares that its solid compound is 'low calorie,' since it has $3.5 \mathrm{kcal}$, using correctly this information, since the aforementioned resolution determines that portions of foods with caloric values less than or equal to $4 \mathrm{kcal}$ can use the statement 'zero' or 'does not contain' in your label.

The ' $E$ ' brand is a preparation of dehydrated vegetables, according to sellers, which gives the drink a green color. The brand ' $C$ ' has in its constitution Camelia sinensis in the form of green tea powder responsible for its yellowish green coloration.

Chlorophyll is the main pigment in green vegetables and some fruits [20]. It has been linked to prominent human health benefits; however, many other studies have been hampered by the lack of an overall structural analysis of all chlorophyll derivatives emerging in biological metabolism, tissue senescence or during food processing [21]. Carotenoids confer yellow coloration in fruits, vegetables and oils, and they are bioactive compounds that have the function of provitamin $A$ ( $\beta$-carotene and $\beta$-cryptoxanthin), antioxidant activity and prevent age-related macular degeneration and cataract (lutein) formation [22]. They are highly appreciated pigments as functional components, both for their coloring properties and human health benefits. However, some pigments belonging to the chlorophyll and carotenoid groups are thermolabile and, traditional thermal treatments of sterilization or high pasteurization of solid food products can induce their degradation [23].

The high content of phenolic compounds in ' $A$ ' brand is attributed to its ingredients (dehydrated cabbage powder, dehydrated spinach powder, orange pulp, blueberry pulp, apple pulp and dehydrated parsley-Table 1), the manner in which they were used; dehydrated and pulp that provide higher concentration of plant constituents and other non-plant ingredients such as vitamins added to the formulation, as these can also be quantified by the Folin-Ciocalteu test. The cabbage [24, 25], spinach [26], orange [27], blueberry [28], apple [29] and parsley [30] have been reported to be rich in phenolic compounds and antioxidants.

The antioxidant action, generally in these compounds, is due to the oxide-reduction potential of certain molecules, the ability to compete for active sites and receptors in the various cell structures, and also in the modulation of expression of genes encoding proteins involved in intracellular defense mechanisms against degenerative oxidative processes of cellular structures [31]. Studies have shown that consumption of fruits and vegetables rich in antioxidant compounds and polyphenols has been shown to prevent oxidation of cholesterol and other lipids in the arteries, increase endothelial prostacyclin formation, which inhibits platelet aggregation and reduces vascular tone, contributing to reduction in blood pressure and prevention of the development of cardiovascular diseases [32].

Only the brand ' $\mathrm{A}$ ' declares the amount of vitamin $\mathrm{C}$ on its label $\left(45 \mathrm{mg} 100^{-1}\right)$, but the value found was higher than reported. This difference can be attributed to the fact that ascorbic acid was added to this drink and, even with the processing of the vegetables used, there may have been a residual amount that contributed to increase the value of vitamin $C$. Only the brand ' $A$ ' meets, if consumed only half of what is indicated on the label, the recommendation of daily intake recommended by the Institute of Medicine [33], where $75 \mathrm{mg}$ is indicated for women, $90 \mathrm{mg}$ for men and $45 \mathrm{mg}$ for children. Following the preparation 
recommendation indicated on the packaging of this same brand (20 $200 \mathrm{~mL}^{-1}$ juice), a woman, a man and a child would consume $1.98,1.5$ and 3.97 , respectively, times more vitamin $C$ than recommended. Importantly, the ' $A$ ' brand claims on its packaging that the product is detox, which may induce consumers to adopt it as a convenient way to drink a healthy drink, however, due to the excess of vitamin $C$ in its composition, its formulation should be reviewed and consumers, especially those with a predisposition to kidney problems, should avoid ingesting this drink.

Folchetti et al. [34] reported that vitamin C intake decreased the concentration of oxLDL inflammatory markers. Plasma concentrations of this particle are desirable for prevention of cardiovascular disease such as atherosclerosis. However, excessive vitamin $\mathrm{C}$ intake has been associated with oxalose, a disease characterized by calcium oxalate deposition in tissues. Calcium oxalate is a highly insoluble salt, corresponding to an end product of carbohydrate metabolism, vitamin C and some amino acids [35]. Oxalose is divided into two types and secondary may occur due to increased oxalate intake (ascorbic acid/ vitamin C, ethylene glycol, methoxyflurane and oxalaterich foods such as rhubarb, spinach, beet, chocolate and black tea), increased oxalate metabolism and reduced oxalate excretion. Vitamin C or ascorbic acid is readily converted to oxalate and it is believed that this may result in a hyperoxaluric state. Although there are controversies about its relationship with stone formation, cases of oxalate nephropathy have been reported with vitamin $C$ intake $<2 \mathrm{~g} /$ day, although $2 \mathrm{~g} /$ day was considered a safe upper limit $[34,36,37]$. Among the ingredients of the ' $A$ ' brand, spinach is an oxalate-rich food [37].

The brands ' $A$ ' and ' $F$ ' obtained the highest values of total phenolics and vitamin $C$, and these compounds have antioxidant activity [38]. The Camelia sinensis, present in the ' $C$ ' and ' $F$ ' brands, is reported to be rich in catechins, phenolic compounds, which can represent more than $30 \%$ of the dry weight of the leaf [39].

Martins et al. [40] showed in their review on the in vivo antioxidant activity of phenolic compounds that this subject is one of the 'hot topics' among the scientific community; however, in vitro studies are the most common. However, according to the same authors, these studies do not consider the necessary biochemical, metabolic and physiological parameters, since both synthetic and natural antioxidants undergo numerous biochemical reactions during ingestion, digestion and absorption by the body. Therefore, and despite current advances, the effective bioavailability of different antioxidants is not clearly defined: While many of them are ingested in their active form, others need to be metabolized to become biologically active or even inactive, in addition, the co-ingestion of other nutrients as well as many endogenous factors and inter- and intra-individual variations affect their availability relative to the ingested dose. These facts explain why some plant species and even their isolated compounds do not show positive effects through in vitro studies, but a strong antioxidant potential is observed when in vivo studies are performed and vice versa [40].

The total dietary fiber content found in the ' $D$ ' and ' $F$ ' brands was 0.1 and $2.47 \%$, respectively, values close to those described on their labels, considering a portion of $100 \mathrm{~mL}$. Other brands declare no significant amounts of dietary fiber. Adequate dietary fiber intake seems to reduce the risk of developing some chronic diseases such as coronary artery disease, stroke, high blood pressure, diabetes mellitus and some gastrointestinal disorders. In addition, increased fiber intake improves serum lipid levels, lowers blood pressure levels, improves glycemic control in patients with diabetes mellitus, assists in reducing body weight and even improves immune system [41]. Current recommendations for dietary fiber intake vary according to age, sex and energy intake, with an appropriate recommendation being around $14 \mathrm{~g}$ of fiber for every $1000 \mathrm{kcal}$ ingested $[33,41]$. Therefore, both drinks can contribute to the daily diet of dietary fiber.

\section{Conclusion}

The beverages analyzed are in accordance with the literature for acidity, except the ' $E$ ' brand. The sugar content found in three brands ('A,' $B$-Le' and ' $D$ ') was higher than that stated on the labels, and the ' $A$ ' brand misleads the consumer by reporting that their drink is 'zero sugar.' In general, the drinks showed yellowish color, except the ' $E$ ' brand with greenish coloration. The brand ' $A$ ' also had higher levels of vitamin $C$ than established by law. The amount of phenolic compounds was higher in the ' $A$ ' and ' $F$ ' brands. Antioxidant content was higher in ' $A$, ' $C$ ' and ' $F$ ' brands. The ' $D$ ' and ' $F$ ' brands were shown as sources of dietary fiber. The content of some brands analyzed is in disagreement with their labels, thus inducing the consumer to error at the time of purchase, which represents a danger to consumers with some kind of food restriction.

Acknowledgements The authors would like to thank the Coordination of Improvement of Higher Education Personnel (Coordenação de Aperfeiçoamento de Pessoal de Nível Superior-CAPES), the National Council for Scientific and Technological Development (Conselho Nacional de Desenvolvimento Científico e Tecnológico-CNPq) and Foundation for Research Support of the State of Minas Gerais (FAPEMIG) for their fundamental financial support for this work. 


\section{Compliance with ethical standards}

Conflict of interest All authors declare no conflict of interest.

\section{References}

1. Bvenura C, Sivakumar D (2017) The role of wild fruits and vegetables in delivering a balanced and healthy diet. Food Res Int 99:15-30

2. Hall JN, Moore S, Harper SB, Lynch JW (2009) Global variability in fruit and vegetable consumption. Am J Prev Med 36(5):402-409

3. Hyson DA (2015) A review and critical analysis of the scientific literature related to $100 \%$ fruit juice and human health. Adv Nutr 6:37-51. https://doi.org/10.3945/an.114.005728

4. Tonin FS, Steimbach LM, Wiens A, Perlin CM, Pontarolo R (2015) Impact of natural juice consumption on plasma antioxidant status: a systematic review and meta-analysis. Molecules 20:2214622156. https://doi.org/10.3390/molecules201219834

5. Tetra Pak. Insights e Oportunidades Associadas ao Suco 100\%: Uma Visão Global https://assets.tetrapak.com/static/br/docum ents/juice_index_2016.pdf. Acessada em 2 Nov 2017

6. AOAC (2016) Official methods of analysis of the Association of Official Analytical Chemistry, 1115 p. Washington

7. INSTITUTO ADOLFO LUTZ (2008) Normas analíticas do Instituto Adolfo Lutz: métodos químicos e físicos para análise de alimentos, 4th ed. São Paulo, $371 \mathrm{p}$

8. Dische Z (1962) General color reactions. In: Whistler RL, Wolfran ML (eds) Carboydrates chemistry, vol 1. Academic Press, New York, pp 477-512

9. McGuire RG (1992) Reporting of objective color measurements. HortScience 17:1254-1255

10. Waterhouse AL (2002) Polyphenolics: determination of total phenolics. In: Wrolstad RE (ed) Current protocols in food analytical chemistry. Wiley, New York, pp 1073-1080

11. Strohecker R, Henning HM (1967) Analisis de vitaminas: métodos comprobados. Paz Montalvo, Madrid

12. Duarte-Almeida JM et al (2006) Avaliação da atividade antioxidante utilizando sistema $\beta$-caroteno/ácido linoleico e método de sequestro de radicais DPPH. Ciência e Tecnologia de Alimentos, Campinas 26(2):446-452

13. Brand-Wiliams W, Cuvelier ME, Berset C (1995) Use of a free radical method to evaluate antioxidant activity. Food Sci Technol 28(1):25-30

14. do Rufino MSM, Alves RE, de Morais SM, de Sampaio CG, PerezJimenez J, Saura-Calixto FD (2007) Metodologia Científica: Determinação da atividade antioxidante total em frutas pela captura do radical livre DPPH. Comunicado TécnicoEmbrapa, Fortaleza, CE

15. Ferreira DF (2011) Sisvar: a computer statistical analysis system. Ciênc Agrotecnol 35(6):1039-1042

16. Rocha LOF, Pimenta CJ, Pereira PAP (2013) Avaliação das características de qualidade de néctares de goiaba light de diferentes marcas comercializadas em lavras/mg. Rev Bras Tecnol Agroind 07(01):911-921

17. Humera $E$, Schedleb K (2016) Fermentation of food and feed: a technology for efficient utilization of macro and trace elements in monogastrics. J Trace Elem Med Biol 37:69-77

18. Andrés V, Tenorio MD, Villanueva MJ (2015) Sensory profile, soluble sugars, organic acids, and mineral content in milk- and soy-juice based beverages. Food Chem 173:1100-1106

19. Brasil (2003) RESOLUÇÃO - RDC No 360, DE 23 DE DEZEMBRO DE 2003. Ministério da Saúde Agência Nacional de Vigilância Sanitária
20. Zhang Z, Wang L, Zeng X, Han Z, Wang M (2017) Effect of pulsed electric fields (PEFs) on the pigments extracted from spinach (Spinacia oleracea L.). Innov Food Sci Emerg Technol 43:26-34

21. Chen K, Ríos JJ, Pérez-Gálvez A, Roca M (2015) Development of an accurate and high-throughput methodology for structural comprehension of chlorophylls derivatives. (I) Phytylated derivatives. J Chromatogr A 1406:99-108

22. Aparicio-Ruiz R, Gandul-Rojas B (2014) Decoloration kinetics of chlorophylls and carotenoids in virgin olive oil by autoxidation. Food Res Int 65:199-206

23. Sánchez C, Baranda AB, Marañón IM (2014) The effect of high pressure and high temperature processing on carotenoids and chlorophylls content in some vegetables. Food Chem 163:37-45

24. Taveira M, Pereira DM, Sousa C, Ferreres F, Andrade PB, Martins A, Pereira JA, Valentão P (2009) In vitro cultures of Brassica oleracea L. var. costata DC: potential plant bioreactor for antioxidant phenolic compounds. J Agric Food Chem 57:1247-1252

25. Jaiswal AK, Gupta S, Abu-Ghannam N (2012) Kinetic evaluation of colour, texture, polyphenols and antioxidant capacity of Irish York cabbage after blanching treatment. Food Chem 131:63-72

26. Khan W, Ramzani PMA, Anjum S, Abbas F, Iqbal M, Yasar A, Ihsan MZ, Anwar MN, Baqar M, Tauqeer HM, Virk ZA, Khan SA (2017) Potential of miscanthus biochar to improve sandy soil health, in situ nickel immobilization in soil and nutritional quality of spinach. Chemosphere 185:1144-1156

27. Espinosa-Pardo FA, Nakajima VM, Macedo GA, Macedo JA, Martínez J (2017) Extraction of phenolic compounds from dry and fermented orange pomace using supercritical $\mathrm{CO}_{2}$ and cosolvents. Food Bioprod Process 101:1-10

28. Wu Y, Zhou Q, Chen X, Li X, Wang Y, Zhang J (2017) Comparison and screening of bioactive phenolic compounds in different blueberry cultivars: evaluation of anti-oxidation and a-glucosidase inhibition effect. Food Res Int 100:312-324

29. Persic M, Mikulic-Petkovsek M, Slatnar A, Veberic R (2017) Chemical composition of apple fruit, juice and pomace and the correlation between phenolic content, enzymatic activity and browning. LWT Food Sci Technol 82:23-31

30. Dadan M, Rybak K, Wiktor A, Nowacka M, Zubernik J (2018) Selected chemical composition changes in microwave-convective dried parsley leaves affected by ultrasound and steaming pre-treatments-an optimization approach. Food Chem 239:242-251

31. Bastos DHM, Rogero MM, Arêas JAG (2009) Mecanismos de ação de compostos bioativos dos alimentos no contexto de processos inflamatórios relacionados à obesidade. Arq Bras Endocrinol Metab 53(5):646-656

32. Wang $X$ et al (2014) Fruit and vegetable consumption and mortality from all causes, cardiovascular disease, and cancer: systematic review and dose-response meta-analysis of prospective cohort studies. BMJ 349(3):و4490

33. Institute of Medicine (2005) Dietary reference intakes: energy, carbohydrate, fiber, fatty acids, cholesterol, protein and amino acids. National Academies Press, Washington, DC

34. Folchetti L, Monfort-Pires M, de Barros CR, Martini L, Ferreira SR (2014) Association of fruits and vegetables consumption and related-vitamins with inflammatory and oxidative stress markers in prediabetic individuals. Diabetol Metab Syndr 6(1):22

35. Bacchetta J, Farlay D, Albelin-Genevois K, Lebourg L, Cochat $P$, Boivin G (2015) Bone impairment in oxalosis: an ultrastructural bone analysis. Bone 81:161-167

36. Sunkara V, Pelkowski TD, Dreyfus D, Satoskar A (2015) Acute kidney disease due to excessive vitamin $C$ ingestion and remote Roux-en-Y gastric bypass surgery superimposed on CKD. Am J Kidney Dis 66(4):721-724

37. Fogo AB, Lusco MA, Najafian B, Alpers CE (2017) AJKD atlas of renal pathology. Oxalosis 69(3):13-14 
38. Fadda A, Serra M, Molinu MG, Azara E, Barberis A, Sanna D (2014) Reaction time and DPPH concentration influence antioxidant activity and kinetic parameters of bioactive molecules and plant extracts in the reaction with the DPPH radical. J Food Compos Anal 35:112-119

39. Fang R, Redfern SP, Kirkup D, Porter EA, Kite GC, Terry LA, Berry MJ, Simmonds MSJ (2017) Variation of theanine, phenolic, and methylxanthine compounds in 21 cultivars of Camellia sinensis harvested in different seasons. Food Chem 220:517-526

40. Martins N, Barros L, Ferreira ICFR (2016) In vivo antioxidant activity of phenolic compounds: facts and gaps. Trends Food Sci Technol 48:1-12
41. Bernaud FSR, Rodrigues TC (2013) Dietary fiber-adequate intake and effects on metabolim health. Arq Bras Endocrinol Metab 57(6):397-405

Publisher's Note Springer Nature remains neutral with regard to jurisdictional claims in published maps and institutional affiliations. 